Pak. j. sci. ind. res. Ser. B: biol. sci. 2020 63B(3) 242-252

\title{
Synergistic Effect of the Combination of Commercial Essential Oils with Standard Antibiotics: In vitro Evaluation
}

\author{
Aneela Mehboob* and Tanveer Abbas \\ Department of Microbiology, University of Karachi, Main University Road, Karachi-75270, Pakistan
}

(received June 22, 2018; revised February 12, 2019; accepted February 15, 2019)

\begin{abstract}
The aim of this investigation was to determine the antibacterial activity of essential oils and to assess the outcomes produced by the combinations of antibiotics and essential oils. To execute this research, gold standard and conventional methods were used. Antibacterial potency of five essential oils namely Citrus limon, Elettaria cardamomum, Lavandula angustifolia, Nigella sativa and Prunus dulcis were tested against Escherichia coli, Serratia fonticola, Serratia liquefaciens, Citrobacter freundii and Staphylococcus aureus recouped from street foods of Karachi. Among five of them, Citrus limon and Lavandula angustifolia were the most potent essential oils showing highest antibacterial activity in their undiluted form with the exception of Staphylococcus aureus but their mix at different concentrations successfully inhibited the growth of Staphylococcus aureus and Serratia fonticola. Synergistic outcomes were achieved against all the tested bacterial strains from the mix of essential oils and antibiotics, however antagonistic results were also obtained. This exploration underpins the application of essential oils alone and in combinations with antimicrobial agents to improve the affectability of ineffective drugs and aides in the advancement of new antimicrobial drugs to treat bacterial infections utilizing therapeutic plants.
\end{abstract}

Keywords: Citrus limon, Elettaria cardamomum, Lavandula angustifolia, Nigella sativa, Prunus dulcis, synergy, foodborne bacteria

\section{Introduction}

Expanding resistance against antimicrobial agents will swiftly increase the odds of morbidity and mortality rate which could seriously influence the health of public. Antimicrobial resistance is turning into a noteworthy issue and the ultimate challenge for the researchers these days. Ready-to-eat foods contaminated with microorganisms are liable for serious life threatening illnesses and an important source of extending resistance from one bacterium to another. From a previous couple of decades, it has been seen that there is an expansion in the cases of foodborne sicknesses and with the progression of time, food isolates are becoming more resistant to antibacterial agents subsequently, their treatment has become more trouble some (Angulo et al., 2009; Yücel et al., 2005; Threlfall et al., 2000).

Traditionally, essential oils have been utilized for down the ages to treat several infectious diseases around the world. Essential oils can be used in different fields such as food, beverages, fragrance and cosmetic industry. The application of essential oils is broad spectrum and

*Author for correspondence;

E-mail: aneelamehboob21@outlook.com also possess varieties of biological activities that can perform an extraordinary part in battling microorganisms (Silva et al., 2010). Several researches have been proven the inborne antimicrobial attributes of essential oils and currently natural therapeutic remedies are the choice of interest over synthetic ones because essential oils are not only used in monotherapy but have been used in combination for many years to reduce the harm of antibiotics (de Rapper et al., 2013; Liu and Nakano, 1996). It was stated in several studies that constituents of essential oils are partitioned into two broad range groups of terpenes, terpenoids, flavonoids, aliphatic compounds and some hydrocarbon that supposed to harm and disturb the cell wall and membrane of micro-organisms by their mechanism of action (Faleiro, 2011; Pichersky et al., 2006). Compounds that are actually present in essential oils obtained from plants, spices and herbs are the primary constituents that can combat against micro-organisms (Kim et al., 1995; Deans and Ritchie, 1987; Janssen et al., 1985). Therefore, essential oils are comprehensively utilized as a part of the medicinal world as natural therapeutic agent. Mode of action of essential oils could be bacteriostatic or bactericidal relying on the concentrations 
used (Guynot et al., 2003). Essential oils of Citrus limon, Lavandula angustifolia, Nigella sativa, Elettaria cardamomum, and Prunus dulcis are well known for their antibacterial, antifungal, antioxidant, and insecticidal properties and many researches have been done on these essential oils (Prabuseenivasan et al., 2006; Cavanagh and Wilkinson, 2002; Randhawa and Al-Ghamdi, 2002) however, very limited literature is available on essential oil of Prunus dulcis and its antimicrobial competences.

The bacterial strains selected in this investigation were recovered from street foods, a research was conducted on the microbial quality of street foods vending in Karachi city (Mehboob and Abbas, 2019). Out of five foodborne bacteria, four were commensal bacteria and one was foodborne pathogen. Food-related diseases are becoming one of the most hazardous worldwide problems. It is estimated that around $30 \%$ of food poisoning cases are reported each year along with $70 \%$ of potential outbreaks risks are associated with street foods consumption (Canini et al., 2013). On the contrary, commensal bacteria are generally harmless for an immuno competent person but they can transfer the resistant gene from one bacterium to another (Paterson, 2006). Researchers mainly focus on the foodborne pathogens like Salmonella spp, Escherichia coli, Staphylococcus aureus and Shigella spp but these commensal bacteria cannot be neglected as the commensal Escherichia coli have the higher prevalence rate of drug resistance than same herd of MDR Salmonella species was depicted by (DeFrancesco et al., 2004).

Because of massive resistance produced by microbes through various mutational process against antimicrobial agents creating pressure on researchers to discover new approaches or remake old ones by using essential oils and plant extracts alone or in combinations for the treatment of diseases (Fisher and Phillips, 2009; Rios and Recio, 2005). Therefore, the aim of this study was the assessment of the antimicrobial significance of essential oils and their in vitro possible interactions with antibiotics against bacterial strains recovered from the street foods of Karachi.

\section{Materials and Methods}

Essential oils. Five essential oil samples of almond (Prunus dulcis), black seed (Nigella sativa), green cardamom (Elettaria cardamomum), lavender (Lavandula angustifolia), and lemon (Citrus Limon) were used in this study to evaluate their antimicrobial potentials. Essential oils of Prunus dulcis and Nigella sativa were commercially purchased from local market, while essential oils of Elettaria cardamomum, Lavandula angustifolia, and Citrus limon were kindly supplied by Noor Oil depot, Karachi, Pakistan.

Tested microorganisms. The antibacterial activity of these commercially purchased EO was assessed against five foodborne bacteria that recuperated from the famous street food shops of Karachi. All these five bacterial strains including gram-negative Escherichia coli, Citrobacter freundii, Serratia fonticola, Serratia liquefaciens, and gram-positive Staphylococcus aureus were isolated and identified according to Bergey's manual of determinative biology (Holt et al., 1994) and ABIS online software (Costin and Ionut, 2017).

Antimicrobial screening of essential oils. Drop agar diffusion method. Drop agar diffusion technique was executed to evaluate the antibacterial potentials of undiluted EO proposed by (Lopes-Lutz et al., 2008; Cruz et al., 2007; Hili, 2001; Hammer et al., 1999). The Mueller Hinton agar plates were inoculated with the test organisms standardize to $0.5 \mathrm{McF}$ arland concentration. $10 \mu \mathrm{L}$ drop of essential oil was placed on Mueller Hinton agar plates and then left untouched for proper dispersion of oils at ambient temperature. After a while, plates were incubated at $37 \pm 1{ }^{\circ} \mathrm{C}$ for $24 \mathrm{~h}$. After incubation, zone of inhibition around each drop was measured in millimeters.

Agar well diffusion method. To analyze the alone and combined effects of EO, the agar well diffusion method was performed according to the method proposed by (Pasha et al., 2018; Martins et al., 2013).

Minimal inhibitory concentration (MIC). Minimum inhibitory concentration is generally considered as a measure of antimicrobial performance of EO. Determination of MIC assay was accomplished as described by (Weerakkody et al., 2010). Different concentrations of EO $(1000,500,250,125,62.5,15.625 \mu \mathrm{g} / \mathrm{mL})$ were prepared in $40 \%$ DMSO. $1000 \mu \mathrm{L}$ aliquots of sterile Mueller Hinton broth was dispensed in Eppendorf tubes containing various concentrations of EO and $10 \mu \mathrm{L}$ bacterial suspension ( $0.5 \mathrm{McF}$ arland concentration). Positive control also run concurrently. Then tubes were 
incubated for overnight at $37 \pm 1{ }^{\circ} \mathrm{C}$. After incubation, bacterial growth was observed by the presence and absence of turbidity (Han et al., 2008).

Antibiotics. The standard antibiotics used were tetracycline $(30 \mu \mathrm{g})$, chloramphenicol $(30 \mu \mathrm{g})$, gentamicin $(10 \mu \mathrm{g})$, amoxicillin $(10 \mu \mathrm{g})$, levofloxacin $(5 \mu \mathrm{g})$, streptomycin $(10 \mu \mathrm{g})$, and oxacillin $(1 \mu \mathrm{g})$. These antibiotics were purchased from Thermo Fischer Scientific Oxoid ltd.

\section{Determination of the synergistic effect of antibiotics} and essential oils on tested organisms. To evaluate the combined impact of both EO and standard antibiotics on tested organisms, disk diffusion method was performed as described by (Mahmoud et al., 2016; Moussaoui and Alaoui, 2016; Toroglu, 2007). $10 \mu \mathrm{L}$ drop of undiluted EO were soaked on antibiotics disc, then plates were allowed to dry for proper diffusion of oils and then plates were incubated at $37 \pm 1{ }^{\circ} \mathrm{C}$ for overnight. Next day the zone of inhibition around each disc was observed and results were compared between alone and combined interaction of EO and antibiotics.

Scanning electron microscopy. Scanning electron microscopy was performed with JEOL from Japan (model \# JSM-6380) located at Centralized Science Laboratories, University of Karachi. Fresh culture of selected strains of Escherichia coli and Staphylococcus aureus (18 h old) were standardized with $0.5 \mathrm{McFarl}$ and index. $10 \mu \mathrm{L}$ of each selected bacterial suspension was inoculated into the micro centrifuge tube containing Mueller Hinton broth and MIC of EO and incubated at $37^{\circ} \mathrm{C}$ for $18 \mathrm{~h}$. Control tubes having bacterial suspension were also run alongside. After overnight incubation, $10 \mu \mathrm{L}$ crystal violet was added in microcentrifuge tubes and let it stand for $1 \mathrm{~min}$. The tubes were centrifuged at $11,000 \mathrm{rpm}$ for 10 mins. After 3 washes with ethanol at 70,80 and $90 \%$, the specimens (bacterial cells) were coated up to $300 \mathrm{~A}^{\circ}$ with gold using smart coater with an ion sputtering device (model JFC-1500) and energy dispersive X-ray spectroscopy detector (model EX-54175JMU; JEOL, Tokyo, Japan). Finally, morphological alterations in the bacterial cell before and after treatment were observed under scanning electron microscope.

Statistical analysis. All experimental analyses were done in triplicates and interpretations were presented as Mean \pm Standard deviation.

\section{Results and Discussion}

Citrus limon and Lavandula angustifolia were showed as the most potent EO among five of them as clearly observed in (Table 1). The least MIC of Lavandula angustifolia was $250 \mu \mathrm{g} / \mathrm{mL}$ for Staphylococcus aureus, Serratia liquefaciens and Citrobacter freundii but for Escherichia coli and Serratia fonticola, the MIC were $1000 \mu \mathrm{g} / \mathrm{mL}$ and $500 \mu \mathrm{g} / \mathrm{mL}$ respectively. While, the lowest MIC of Citrus limon against all the selected strains was $500 \mu \mathrm{g} / \mathrm{mL}$ except for Escherichia coli with the MIC was $1000 \mu \mathrm{g} / \mathrm{mL}$. Although, rest of the EO were not able to demonstrate their antibacterial proficiency in agar well diffusion method. Macro broth dilution method was performed to determine the MIC of EO that inhibit the visible growth of bacteria (Delaquis et al., 2002).

All the EO in broth medium produced competent results against all the tested organisms as presented in (Table 2). EO of Elettaria cardamomum was the most effective EO, repressed the growth of all foodborne bacteria at $62.5 \mu \mathrm{g} / \mathrm{mL}$ aside from Serratia liquefaciens with the MIC was $250 \mu \mathrm{g} / \mathrm{mL}$ followed by Nigella sativa and Prunus dulcis, both the EO showed variable levels of inhibition. For Nigella sativa EO, Escherichia coli, Staphylococcus aureus and Serratia liquefaciens and in case of Prunus dulcis EO, Citrobacter freundii, Serratia fonticola and Staphylococcus aureus were the most susceptible bacteria because of their low MIC $(62.5 \mu \mathrm{g} / \mathrm{mL})$. Similarly the highest MIC values of the EO of Nigella sativa (125-1000 $\mu \mathrm{g} / \mathrm{mL})$ were determined against Serratia fonticola and Citrobacter freundii. Whereas, the highest MIC values $(250-1000 \mu \mathrm{g} / \mathrm{mL})$ of Prunus dulcis EO were found against Serratia liquefaciens and Escherichia coli. The obtained MIC of Citrus limon and Lavandula angustifolia EO ranges in between $(125,250$ and $1000 \mu \mathrm{g} / \mathrm{mL})$ against all the tested strains. The variations were noticed in the MIC values of agar well diffusion and macro broth dilution method when compared are due to the nature of antimicrobial compounds. Some of the antimicrobial compounds were not properly diffused into the solid medium because of their low polarities hence unable to show their antibacterial traits. Several studies have been done on EO possessed biological activities such as Elettaria cardamomum proved itself as a competent candidate to battle against different diseases such as 
Table 1. Antibacterial activity of essential oils of Citrus limon, Lavandula angustifolia, Nigella sativa, Elettaria cardamomum, and Prunus dulcis by agar well diffusion method ${ }^{\mathrm{a}}$

\begin{tabular}{|c|c|c|c|c|c|c|c|c|}
\hline \multirow[t]{3}{*}{ Bacterial strains } & \multirow[t]{2}{*}{ Citrus limon } & \multicolumn{6}{|c|}{ Lavandula angustifolia } & \multirow{2}{*}{$\begin{array}{l}\text { Nigella sativa, } \\
\text { Elettaria } \\
\text { cardamomum, } \\
\text { \& Prunus dulcis }\end{array}$} \\
\hline & & & \multicolumn{5}{|c|}{$\begin{array}{l}\text { Essential Oils concentration in }(\mu \mathrm{g} / \mathrm{mL}) \\
\text { Zone of inhibition in } \mathrm{mm}\end{array}$} & \\
\hline & 1000 & 500 & 250,125 & $\begin{array}{l}1000 \\
62.5 \& \\
15.6\end{array}$ & 500 & 250 & $\begin{array}{l}125, \\
62.5 \& \\
15.6\end{array}$ & 1000 to 15.6 \\
\hline $\begin{array}{l}\text { Staphylococcus } \\
\text { aureus }\end{array}$ & $20 \pm 0.0$ & $20 \pm 0$ & $\mathrm{~N} / \mathrm{D}$ & $19.6 \pm 0.34$ & $18.9 \pm 0.17$ & $29.9 \pm 0.17$ & N/D & N/D \\
\hline Escherichia coli & $15.5 \pm 0.5$ & $\mathrm{~N} / \mathrm{D}$ & $\mathrm{N} / \mathrm{D}$ & $29.43 \pm 0.51$ & $\mathrm{~N} / \mathrm{D}$ & $\mathrm{N} / \mathrm{D}$ & $\mathrm{N} / \mathrm{D}$ & $\mathrm{N} / \mathrm{D}$ \\
\hline $\begin{array}{l}\text { Serratia } \\
\text { liquefaciens }\end{array}$ & $19.8 \pm 0.34$ & $20 \pm 0$ & $\mathrm{~N} / \mathrm{D}$ & $19.93 \pm 0.11$ & $19.66 \pm 0.28$ & $12.67 \pm 0.57$ & $\mathrm{~N} / \mathrm{D}$ & $\mathrm{N} / \mathrm{D}$ \\
\hline $\begin{array}{l}\text { Citrobacter } \\
\text { freundii }\end{array}$ & $20 \pm 0$ & $19.8 \pm 0.34$ & $\mathrm{~N} / \mathrm{D}$ & $\mathrm{N} / \mathrm{D}$ & $\mathrm{N} / \mathrm{D}$ & $14.67 \pm 0.5$ & $\mathrm{~N} / \mathrm{D}$ & $\mathrm{N} / \mathrm{D}$ \\
\hline $\begin{array}{l}\text { Serratia } \\
\text { fonticola }\end{array}$ & $20 \pm 0$ & $20 \pm 0$ & $\mathrm{~N} / \mathrm{D}$ & $20 \pm 0$ & $20 \pm 0$ & $10 \pm 0$ & N/D & N/D \\
\hline
\end{tabular}

${ }^{\mathrm{a}} \mathrm{N} / \mathrm{D}=$ No detection of antibacterial activity; values are means of triplicates $\pm \mathrm{SD}$.

Table 2. Minimum Inhibitory concentration determined by broth dilution method

\begin{tabular}{|c|c|c|c|c|c|}
\hline \multirow[t]{2}{*}{ Bacterial strains } & \multicolumn{5}{|c|}{ MIC of Essential oils $(\mu \mathrm{g} / \mathrm{mL})$} \\
\hline & Prunus dulcis & Elettaria cardamomum & Nigella sativa & $\begin{array}{l}\text { Lavandula } \\
\text { angustifolia }\end{array}$ & Citrus limon \\
\hline Escherichia coli & 1000 & 62.5 & 62.5 & 250 & 250 \\
\hline Staphylococcus aureus & 62.5 & 62.5 & 62.5 & 125 & 250 \\
\hline Serratia liquefaciens & 250 & 250 & 62.5 & 1000 & 125 \\
\hline Citrobacter freundii & 62.5 & 62.5 & 1000 & 1000 & 1000 \\
\hline Serratia fonticola & 62.5 & 62.5 & 125 & 1000 & 1000 \\
\hline
\end{tabular}

gastrointestinal disturbances and known to be utilized in cooking to augment the deliciousness of food (Evans, 2002). Similarly, Citrus limon and Nigella sativa are heavily loaded with bioactive compounds to combat against a wide range of bacteria (Prabuseenivasan et al., 2006). While the EO of Lavandula angustifolia is well known to refresh mind and have healing properties. EO of Lavandula angustifolia reportedly used in combination with multiple oils and produced synergistic effects against microorganisms (Buckle, 2014; de Rapper et al., 2013; Shealy, 1998; Lawless, 1995).

EO of Citrus limon and Lavandula angustifolia exhibited significant antibacterial activity against all the tested foodborne isolates with an exception of Staphylococcus aureus while no antibacterial activity was distinguished against rest of the EO in their neat (undiluted) form as summarized in Table 3-7. As demonstrated by the obtained results, the combinations of five $\mathrm{EO}$ with seven tested antibiotics produced synergistic impact against all the selected foodborne bacteria. EO of Citrus limon with all the tested antibiotics showed synergistic effect against Staphylococcus aureus and antagonistic effect against Serratia liquefaciens and Citrobacter freundii. Synergistic effect was seen against Escherichia coli and Serratia liquefaciens, while the combination of EO of Nigella sativa and chloramphenicol and gentamicin were applied, respectively. The mix of Nigella sativa with levofloxacin, gentamicin, tetracycline, and streptomycin produced synergistic effect against Citrobacter 
Table 3. Antibacterial activity of essential oil of Citrus limon and its combined effects with standard antibiotics ${ }^{\mathrm{a}}$

\begin{tabular}{|c|c|c|c|c|c|c|c|c|c|c|c|c|c|c|c|}
\hline \multirow{3}{*}{$\begin{array}{l}\text { Bacterial } \\
\text { strains }\end{array}$} & \multicolumn{15}{|c|}{ Zone of inhibition in millimeters (mm) } \\
\hline & \multicolumn{4}{|c|}{$\overline{\mathrm{A}}$} & \multicolumn{5}{|c|}{ B } & \multirow[b]{2}{*}{$\mathrm{O}$} & \multirow[b]{2}{*}{ M } & \multirow[b]{2}{*}{ C } & \multicolumn{3}{|c|}{$\mathrm{C}$} \\
\hline & $\mathrm{CL}$ & $\mathrm{L}$ & $\mathrm{O}$ & M & $\mathrm{C}$ & $\mathrm{CN}$ & $\mathrm{T}$ & $P$ & $\mathrm{~L}$ & & & & $\mathrm{CN}$ & $\mathrm{T}$ & $\mathrm{P}$ \\
\hline \multirow[t]{2}{*}{$\mathrm{EC}$} & 14.86 & 29.5 & $\mathrm{R}$ & $\mathrm{R}$ & 24.3 & $17 \pm 0$ & $26 \pm 0$ & 11.93 & $25 \pm 0 \mathrm{a}$ & $6 \pm 0 \mathrm{a}$ & $19.9 \pm$ & $25 \pm 0 \mathrm{a}$ & $20 \pm 0 \mathrm{a}$ & $24.93 \pm$ & $15 \pm 0 \mathrm{a}$ \\
\hline & \pm 0.2 & \pm 0.7 & & & \pm 0.5 & & & \pm 0.11 & & & $0.11 \mathrm{~s}$ & & & $0.11 \mathrm{a}$ & \\
\hline \multirow[t]{2}{*}{ SF } & $10 \pm 0$ & 26.5 & $\mathrm{R}$ & $\mathrm{R}$ & 24.2 & 16.3 & 28.2 & 10.5 & 9.93 & $6 \pm 0 \mathrm{a}$ & 28.96 & $23 \pm 0 \mathrm{a}$ & 14.83 & 22.56 & $6 \pm 0 \mathrm{a}$ \\
\hline & & \pm 0.7 & & & \pm 0.4 & \pm 0.5 & \pm 0.40 & \pm 0.70 & $\pm 0.1 \mathrm{a}$ & & $\pm 0.05 \mathrm{~s}$ & & $\pm 0.28 \mathrm{a}$ & $\pm 0.49 \mathrm{a}$ & \\
\hline \multirow[t]{2}{*}{ SL } & $9.93 \pm$ & $25.6 \pm$ & $\mathrm{R}$ & $\mathrm{R}$ & $21.9 \pm$ & $14.1 \pm$ & $25.8 \pm$ & $13.1 \pm$ & $22 \pm 0 \mathrm{a}$ & $6.93 \pm$ & $8.93 \pm$ & $20 \pm 0 \mathrm{a}$ & $18 \pm 0 \mathrm{a}$ & $18 \pm 0 \mathrm{a}$ & $15 \pm 0 \mathrm{a}$ \\
\hline & 0.1 & 0.5 & & & 0.05 & 0.28 & 0.28 & 0.17 & & $0.11 \mathrm{a}$ & $0.11 \mathrm{a}$ & & & & \\
\hline \multirow[t]{2}{*}{ SA } & $\mathrm{N} / \mathrm{D}$ & $26 \pm 0$ & $\mathrm{R}$ & $\mathrm{R}$ & $22.1 \pm$ & $22 \pm$ & $26.1 \pm$ & $17.2 \pm 0$ & $29.8 \pm$ & $14.8 \pm$ & $30 \pm 0 \mathrm{~s}$ & $34.5 \pm$ & $35.73 \pm$ & $40 \pm 0 \mathrm{~s}$ & $24.96 \pm$ \\
\hline & & & & & 0.1 & 0.2 & 0.17 & .34 & $0.34 \mathrm{~s}$ & $0.26 \mathrm{~s}$ & & $0.5 \mathrm{~s}$ & $0.25 \mathrm{~s}$ & & $0.05 \mathrm{~s}$ \\
\hline \multirow[t]{2}{*}{$\mathrm{CF}$} & $19 \pm 0$ & $22 \pm 0$ & $\mathrm{R}$ & $\mathrm{R}$ & $22.3 \pm$ & $16 \pm 0$ & $23.7 \pm$ & $12 \pm 0$ & $25 \pm 0 \mathrm{a}$ & $10 \pm 0 \mathrm{a}$ & $8.93 \pm$ & $25 \pm 0 \mathrm{a}$ & $16.8 \pm$ & $22 \pm 0 \mathrm{a}$ & $12 \pm 0 \mathrm{a}$ \\
\hline & & & & & 0.5 & & 0.57 & & & & $0.11 \mathrm{a}$ & & $0.34 \mathrm{a}$ & & \\
\hline
\end{tabular}

${ }^{\mathrm{a}} \mathrm{A}=$ Inhibition zones that occurred with essential oil (essential oil of Citrus limon: $10 \mu \mathrm{L}$ ); $\mathrm{B}=$ Inhibition zones that occurred with standard antibiotic disc, levofloxacin (L), oxacillin (O), amoxicillin; (M), chloramphenicol (C), gentamicin (CN), tetracycline $(\mathrm{T})$, and streptomycin $(\mathrm{P}) ; \mathrm{C}=$ Inhibition zones that occurred when essential oil and standard antibiotic were used together, (essential oil of Citrus limon $10 \mu \mathrm{L} / \mathrm{disc}) ;(\mathrm{CL}=$ Citrus limon; $\mathrm{EC}=$ Escherichia coli; $\mathrm{SF}=$ Serratia fonticola, $\mathrm{SL}=$ Serratia liquefaciens, $\mathrm{CF}=$ Citrobacter freundii; $\mathrm{SA}=$ Staphylococcus aureus; $\mathrm{N} / \mathrm{D}=$ no antibacterial activity detected; $\mathrm{s}=$ Synergism effect; $\mathrm{e}=$ Additive effect; $\mathrm{a}=$ Antagonistic effect; $\mathrm{i}=$ Indifference; $\mathrm{R}=$ resistant; Values are represented as Mean $\pm \mathrm{SD})$.

Table 4. Antibacterial activity of essential oil of Lavandula angustifolia and its combined effects with standard antibiotics $^{\mathrm{a}}$

\begin{tabular}{|c|c|c|c|c|c|c|c|c|c|c|c|c|c|c|c|}
\hline \multirow{3}{*}{$\begin{array}{l}\text { Bacteria } \\
\text { strains }\end{array}$} & \multicolumn{15}{|c|}{ Zone of inhibition in millimeters $(\mathrm{mm})$} \\
\hline & \multicolumn{9}{|l|}{$\mathrm{A}$} & \multicolumn{6}{|c|}{$\mathrm{C}$} \\
\hline & $\mathrm{V}$ & $\mathrm{L}$ & $\mathrm{O}$ & M & $\mathrm{C}$ & $\mathrm{CN}$ & $\mathrm{T}$ & $\mathrm{P}$ & $\mathrm{L}$ & $\mathrm{O}$ & M & $\mathrm{C}$ & $\mathrm{CN}$ & $\mathrm{T}$ & $\mathrm{P}$ \\
\hline \multirow[t]{2}{*}{$\mathrm{EC}$} & $13.06 \pm$ & $29.5 \pm$ & $\mathrm{R}$ & $\mathrm{R}$ & $24.3 \pm$ & $17 \pm 0$ & $26 \pm 0$ & $11.93 \pm$ & $30 \pm 0 \mathrm{a}$ & a & $21.9 \pm$ & $28 \pm 0 \mathrm{a}$ & $25 \pm 0 \mathrm{a}$ & $26.1 \pm$ & $20.1 \pm$ \\
\hline & 0.11 & 0.7 & & & 0.5 & & & 0.11 & & & $0.17 \mathrm{~s}$ & & & $0.23 \mathrm{I}$ & $0.17 \mathrm{a}$ \\
\hline \multirow[t]{2}{*}{ SF } & $9.9 \pm$ & $26.5 \pm$ & $\mathrm{R}$ & $\mathrm{R}$ & $24.2 \pm$ & $16.3 \pm$ & $28.2 \pm$ & $10.5 \pm$ & $\mathrm{a}$ & $\mathrm{a}$ & $\mathrm{a}$ & $7.9 \pm$ & $\mathrm{a}$ & $\mathrm{a}$ & $9 \pm 0 \mathrm{a}$ \\
\hline & 0.17 & 0.7 & & & 0.4 & 0.5 & 0.40 & 0.70 & & & & $0.17 \mathrm{a}$ & & & \\
\hline \multirow[t]{2}{*}{ SL } & $11.67 \pm$ & $25.6 \pm$ & $\mathrm{R}$ & $\mathrm{R}$ & $21.9 \pm$ & $14.1 \pm$ & $25.8 \pm$ & $13.1 \pm$ & $18.1 \pm$ & $\mathrm{a}$ & $5 \pm 0 \mathrm{a}$ & $22 \pm 0 \mathrm{a}$ & $22.73 \pm$ & $18 \pm 0 \mathrm{a}$ & $20 \pm 0 \mathrm{a}$ \\
\hline & 0.57 & 0.5 & & & 0.05 & 0.28 & 0.28 & 0.17 & $0.17 \mathrm{a}$ & & & & $0.46 \mathrm{a}$ & & \\
\hline \multirow[t]{2}{*}{ SA } & $\mathrm{N} / \mathrm{D}$ & $26 \pm 0$ & $\mathrm{R}$ & $\mathrm{R}$ & $22.1 \pm$ & $22 \pm$ & $26.1 \pm$ & $17.2 \pm$ & $21.9 \pm$ & N/D & $10 \pm 0 \mathrm{a}$ & $12 \pm 0 \mathrm{a}$ & $17.86 \pm$ & $15 \pm 0 \mathrm{a}$ & $10 \pm 0 \mathrm{a}$ \\
\hline & & & & & 0.1 & 0.2 & 0.17 & 0.34 & $0.17 \mathrm{a}$ & & & & $0.23 \mathrm{a}$ & & \\
\hline \multirow[t]{2}{*}{$\mathrm{CF}$} & $14.83 \pm$ & $22 \pm 0$ & $\mathrm{R}$ & $\mathrm{R}$ & $22.3 \pm$ & $16 \pm 0$ & $23.7 \pm$ & $12 \pm 0$ & $25 \pm 0 \mathrm{a}$ & $\mathrm{a}$ & $10 \pm 0 \mathrm{a}$ & $18 \pm 0 \mathrm{a}$ & $18.06 \pm$ & $21.83 \pm$ & $11 \pm 0 \mathrm{a}$ \\
\hline & 0.28 & & & & 0.5 & & 0.57 & & & & & & $0.11 \mathrm{a}$ & $0.28 \mathrm{a}$ & \\
\hline
\end{tabular}

${ }^{\mathrm{a}} \mathrm{A}=$ Inhibition zones that occurred with essential oil (essential oil of Lavandula: $10 \mu \mathrm{L}$ ); B = Inhibition zones that occurred with standard antibiotic disc, levofloxacin $(\mathrm{L})$, oxacillin $(\mathrm{O})$, amoxicillin; $(\mathrm{M})$, chloramphenicol $(\mathrm{C})$, gentamicin $(\mathrm{CN})$, tetracycline $(\mathrm{T})$, and streptomycin $(\mathrm{P}) ; \mathrm{C}=$ Inhibition zones that occurred when essential oil and standard antibiotic were used together, (essential oil of Lavandula $10 \mu \mathrm{L} /$ disc); $(\mathrm{V}=$ Lavandula angustifolia $; \mathrm{EC}=$ Escherichia coli; $\mathrm{SF}=$ Serratia fonticola; $\mathrm{SL}=$ Serratia liquefaciens $; \mathrm{CF}=$ Citrobacter freundii; $\mathrm{SA}=$ Staphylococcus aureus; and N/D = no antibacterial activity detected; $\mathrm{s}=$ Synergism effect; $\mathrm{e}=$ Additive effect; $\mathrm{a}=$ Antagonistic effect; $\mathrm{i}=$ Indifference; $\mathrm{R}=$ resistant; Values are represented as Mean $\pm \mathrm{SD})$. 
freundii and adversarial impact on rest of the isolates. The combination of EO of Lavandula angustifolia with all the tested antibiotics showed antagonistic effects against all five bacterial strains however, synergistic effect was acquired with amoxicillin against Escherichia coli. Most of the synergistic effect was found with the combination of gentamicin with Elettaria cardamomum EO against Serratia liquefaciens, Escherichia coli and Staphylococcus aureus. Phenomena of synergism was also observed against Staphylococcus aureus, while the combination of Elettaria cardamomum EO and tetracycline and streptomycin were applied. Most of the synergistic outcomes were obtained from EO of Prunus dulcis was alone unable to show their antibacterial potential against these food isolates. Of the combination of Prunus dulcis EO and streptomycin against Escherichia coli, Serratia liquefaciens and Citrobacter freundii synergistic effect was observed. Also the mix of EO of Prunus dulcis with levofloxacin and gentamicin demonstrated synergistic effect against Staphylococcus aureus and Citrobacter freundii respectively. Against Escherichia coli, the previously mentioned mix with both the antibiotics produced synergistic effect.
Synergistic effect of at least two drugs produced surpass results than the sum of their individual effects is called synergism (Singh et al., 2000). Phenomena of synergism can be obtained in multiple circumstances for instance one antibiotic may prevent the inactivation of a second antimicrobial compound by microbial enzyme. Synergistic effect can likewise be seen in such case in which a drug like penicillin inhibit the cell wall synthesis may increase the rate of entrance of aminoglycosides into the bacterial cell therefore, two drugs consecutively obstruct the metabolic pathway of microbes (Brooks et al., 1995).

Worth mentioning of these two drugs namely oxacillin and amoxicillin (beta-lactam drugs) to which all the tested foodborne bacteria showed complete resistance but remarkable results were obtained with the combination of EO and these two antibiotics. It was reported in a study that more than $92 \%$ of staphylococcus have beta-lactamase enzyme hence resistant towards both the derivatives of penicillin (Barry, 1990). The combination of EO of Prunus dulcis with amoxicillin showed significant antibacterial activity against all the tested bacteria. With Elettaria

Table 5. Antibacterial activity of essential oil of Elettaria cardamomum and its combined effects with standard antibiotics $^{\mathrm{a}}$

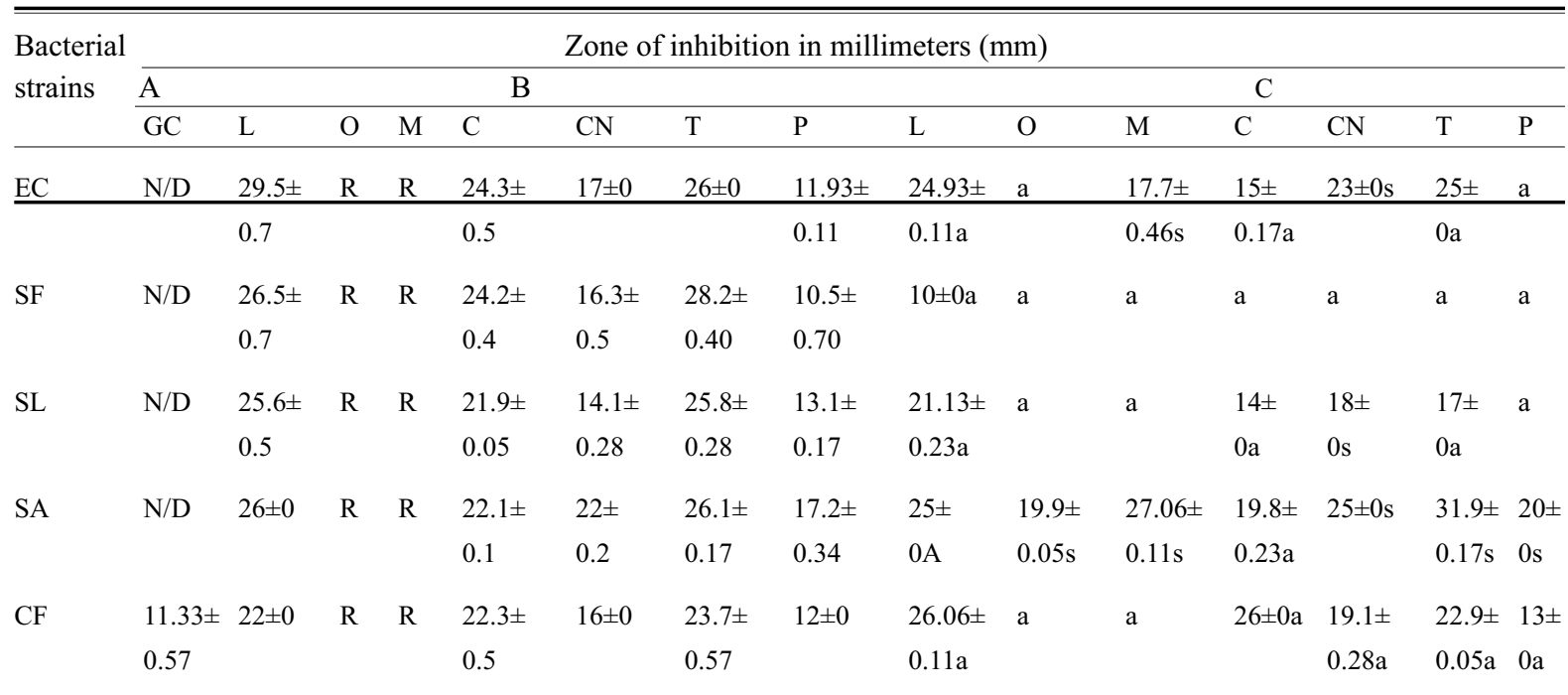

${ }^{\mathrm{a}} \mathrm{A}=$ Inhibition zones that occurred with essential oil (essential oil of Elettaria cardamomum: $10 \mu \mathrm{L}$ ); B = Inhibition zones that occurred with standard antibiotic disc, levofloxacin (L), oxacillin (O), amoxicillin; (M), chloramphenicol (C), gentamicin $(\mathrm{CN})$, tetracycline $(\mathrm{T})$ and streptomycin $(\mathrm{P}) ; \mathrm{C}=$ Inhibition zones that occurred when essential oil and standard antibiotic were used together, (essential oil of Elettaria cardamomum $10 \mu \mathrm{L} /$ disc $) ;(\mathrm{GC}=$ Elettaria cardamomum; $\mathrm{EC}=$ Escherichia coli , SF $=$ Serratia fonticola $; \mathrm{SL}=$ Serratia liquefaciens $; \mathrm{CF}=$ Citrobacter freundii; $\mathrm{SA}=$ Staphylococcus aureus; $/ \mathrm{D}=$ no antibacterial activity detected; $\mathrm{s}=$ Synergism effect; $\mathrm{e}=$ Additive effect; $\mathrm{a}=$ Antagonistic effect, $\mathrm{i}=$ Indifference; $\mathrm{R}=$ resistant; Values are represented as Mean $\pm \mathrm{SD}$ ). 
Table 6. Antibacterial activity of essential oil of Prunus dulcis and its combined effects with standard antibiotics ${ }^{\mathrm{a}}$

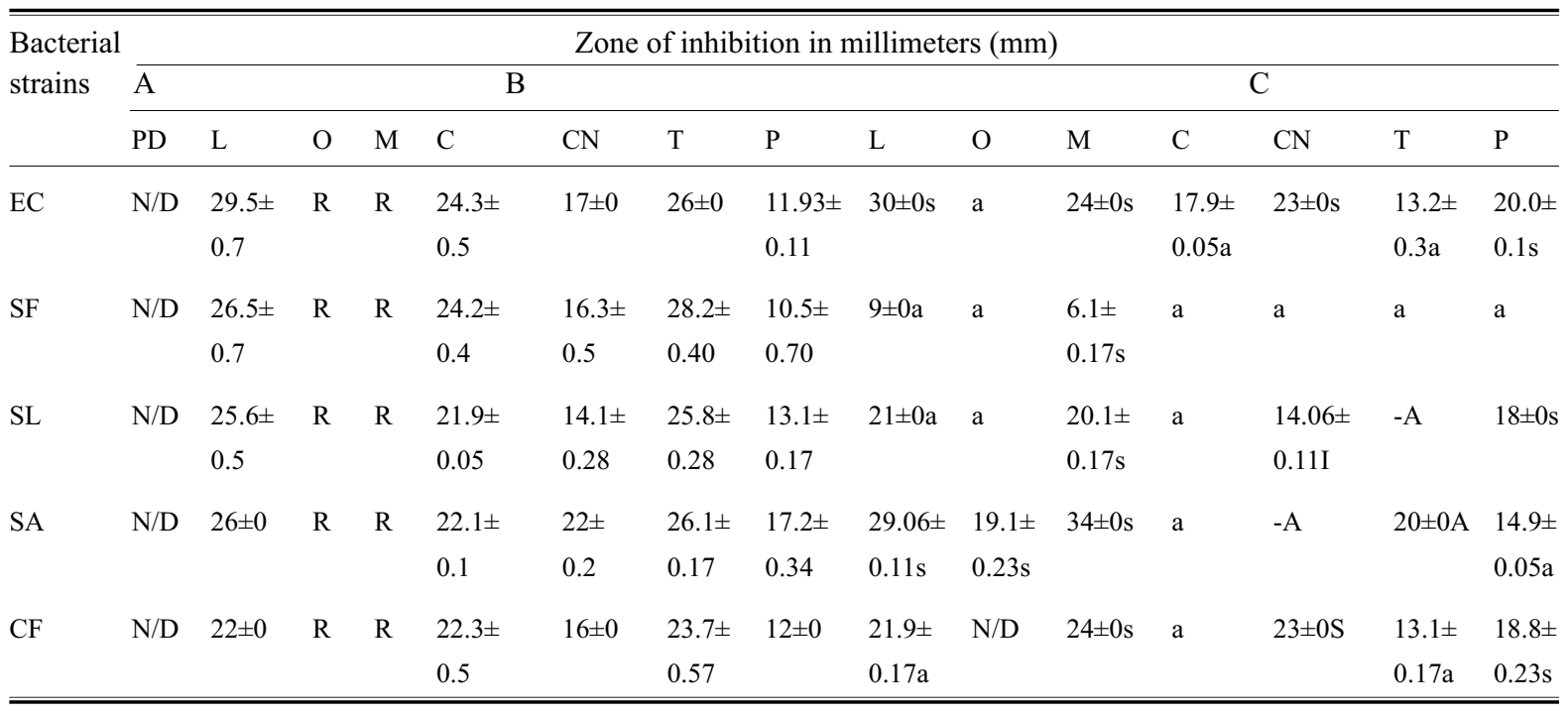

${ }^{\mathrm{a}} \mathrm{A}=$ Inhibition zones that occurred with essential oil (essential oil of Prunus dulcis: $10 \mu \mathrm{L}$ ); $\mathrm{B}=$ Inhibition zones that occurred with standard antibiotic disc, levofloxacin $(\mathrm{L})$, oxacillin $(\mathrm{O})$, amoxicillin $(\mathrm{M})$, chloramphenicol $(\mathrm{C})$, gentamicin $(\mathrm{CN})$, tetracycline $(\mathrm{T})$, and streptomycin $(\mathrm{P}) ; \mathrm{C}=$ Inhibition zones that occurred when essential oil and standard antibiotic were used together, (essential oil of Prunus dulcis $10 \mu \mathrm{L} / \mathrm{disc}) ;(\mathrm{PD}=$ Prunus dulcis; $\mathrm{EC}=$ Escherichia coli; $\mathrm{SF}=$ Serratia fonticola; $\mathrm{SL}=$ Serratia liquefaciens; $\mathrm{CF}=$ Citrobacter freundii; $\mathrm{SA}=$ Staphylococcus aureus; and N/D = no antibacterial activity detected; $\mathrm{s}=$ Synergism effect; $\mathrm{e}=$ Additive effect; $\mathrm{a}=$ Antagonistic effect; $\mathrm{i}=$ Indifference $\mathrm{R}=$ resistant; Values are represented as Mean $\pm \mathrm{SD})$.

cardamomum EO, produced synergistic effect against Escherichia coli and Staphylococcus aureus. Combination of amoxicillin and EO of Nigella sativa and Lavandula angustifolia exhibited synergistic impact against Escherichia coli. Synergy was also seen against Escherichia coli, Serratia fonticola and Staphylococcus aureus with the combination of amoxicillin and EO of Citrus limon. Then again, EO of Prunus dulcis, Elettaria cardamomum and Citrus limon produced synergistic effect against Staphylococcus aureus when combined with oxacillin. This research was supported by the former study conducted on tea tree (Camellia sinensis). EO of tea tree are very effective against pathogenic microbes including methicillin-resistant Staphylococcus aureus. Synergistic effect was noticed against Staphylococcus aureus, while the combination of EO of Camellia sinensis and oxacillin were applied (Abascal and Yarnell, 2002).

EO of Citrus limon and Lavandula angustifolia gave proficient outcomes in their undiluted form against all the tested bacteria except for Staphylococcus aureus demonstrated by drop agar diffusion technique. These two EO were picked to check the consolidated impact in their neat form and at different concentrations obtained by agar well diffusion method. CCL (combination of Citrus limon and Lavandula angustifolia) EO at all the tested concentrations displayed noteworthy synergistic effect against Serratia fonticola. While the additive result was seen against Escherichia coli $(24.8 \pm 0.28$ $\mathrm{mm})$ and Serratia liquefaciens $(15 \pm 0 \mathrm{~mm})$ at 500 $\mu \mathrm{g} / \mathrm{mL}$ and no antibacterial activity was observed against Citrobacter freundii at all the tried concentrations as shown in (Table 8). Synergistic effect was spotted against Staphylococcus aureus at all the tested combinations to which these EO alone were unable to inhibit the growth of Staphylococcus aureus. Scanning electron microscopy was performed to verify antibacterial activity and mode of action of selected EO. Scanning electron microscopic images revealed the alteration in cellular morphology of bacterial cell after treated with EO at the MIC as shown in (Fig. 1). Image (a) and (c) were the control images of Escherichia coli and Staphylococcus aureus respectively which were not exposed to the EO hence the morphology and arrangement of bacterial cells remain unchanged. On the other hand, bacterial cells treated with EO responsible for bulging of cells, disruption of the cell wall and the 
arrangement of bacterial cells were distorted. Components present in the EO for example, thymol, carvacrol, and eugenol are responsible for the disruption of cell membrane. Furthermore, inactivates the microbial enzymes by reacting its active sites was accounted in few studies (Guynot et al., 2003). It can also be hypothesized that the possible mechanism of action of these EO may involve termination of $\mathrm{N}$-acetyl muramic acid linkages, which would subsequently cease the cell wall synthesis (Ginsberg et al., 2006). Therefore, according to the obtained results, it can be hypothesized that the mode of action of tested EO was the cell wall and cell membrane of bacteria. Briefly, all five EO displaced noteworthy results against all five bacterial strains. EO of Citrus limon and Lavandula angustifolia showed their best antibacterial efficiency in solid agar medium while EO of Prunus dulcis, Elettaria cardamomum, and Nigella sativa proved their antibacterial strength in broth medium. In combination with antibiotics, EO of Prunus dulcis was the best of all to produce synergistic effect followed by Citrus limon, Elettaria cardamomum, Nigella sativa, and Lavandula angustifolia. Although antagonistic and additive outcomes were seen as well.

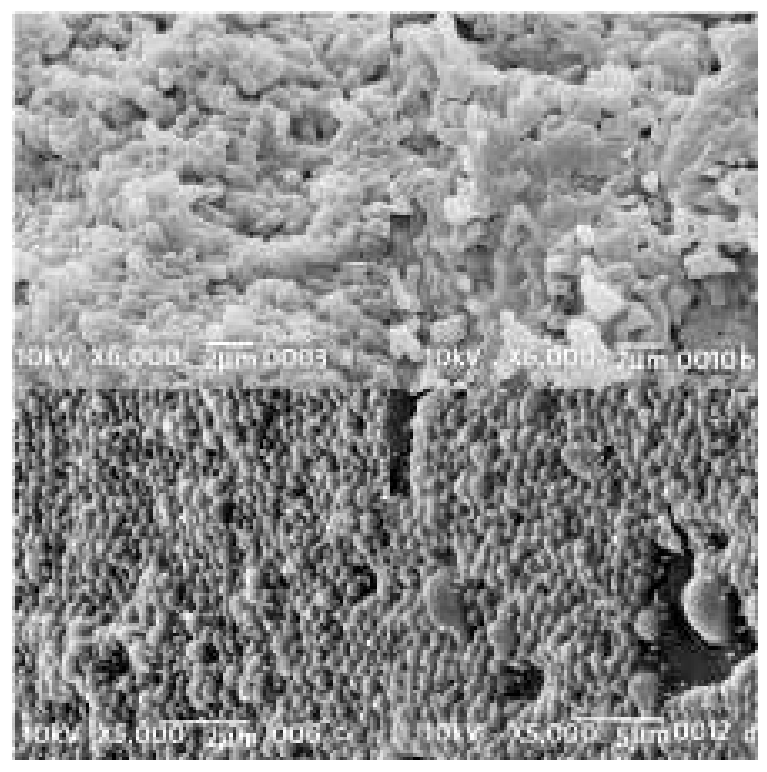

Fig. 1. Scanning electron microscopic images of tested bacteria when treated with EO at MIC. Escherichia coli (a) control (b) treated with EO of Citrus limon at $500 \mu \mathrm{g} / \mathrm{mL}$; Staphylococcus aureus (c) control (d) treated with CCL at $1000 \mu \mathrm{g} / \mathrm{mL}$.

Table 7. Antibacterial activity of essential oil of Nigella sativa and its combined effects with standard antibiotics ${ }^{\mathrm{a}}$

\begin{tabular}{|c|c|c|c|c|c|c|c|c|c|c|c|c|c|c|c|}
\hline \multirow{3}{*}{$\begin{array}{l}\text { Bacterial } \\
\text { strains }\end{array}$} & \multicolumn{15}{|c|}{ Zone of inhibition in millimeters $(\mathrm{mm})$} \\
\hline & \multicolumn{9}{|l|}{$\overline{\mathrm{A}}$} & \multicolumn{6}{|c|}{$\mathrm{C}$} \\
\hline & NS & $\mathrm{L}$ & $\mathrm{O}$ & M & $\mathrm{C}$ & $\mathrm{CN}$ & $\mathrm{T}$ & $\mathrm{P}$ & $\mathrm{L}$ & $\mathrm{O}$ & M & $\mathrm{C}$ & $\mathrm{CN}$ & $\mathrm{T}$ & $\mathrm{P}$ \\
\hline $\mathrm{EC}$ & $\mathrm{N} / \mathrm{D}$ & $\begin{array}{l}29.5 \pm \\
0.7\end{array}$ & $\mathrm{R}$ & $\mathrm{R}$ & $\begin{array}{l}24.3 \pm \\
0.5\end{array}$ & $17 \pm 0$ & $26 \pm 0$ & $\begin{array}{l}11.93 \pm \\
0.11\end{array}$ & $\begin{array}{l}23.96 \pm \\
0.05 \mathrm{a}\end{array}$ & $\mathrm{a}$ & $23 \pm 0 \mathrm{~s}$ & $30 \pm 0 \mathrm{~s}$ & $15 \pm 0 \mathrm{a}$ & $\begin{array}{l}21.96 \pm \\
0 \mathrm{a}\end{array}$ & $\begin{array}{l}11.96 \pm \\
0.05 \mathrm{i}\end{array}$ \\
\hline SF & $\mathrm{N} / \mathrm{D}$ & $\begin{array}{l}26.5 \pm \\
0.7\end{array}$ & $\mathrm{R}$ & $\mathrm{R}$ & $\begin{array}{l}24.2 \pm \\
0.4\end{array}$ & $\begin{array}{l}16.3 \pm \\
0.5\end{array}$ & $\begin{array}{l}28.2 \pm \\
0.40\end{array}$ & $\begin{array}{l}10.5 \pm \\
0.70\end{array}$ & $13 \pm 0 \mathrm{a}$ & a & a & a & $\mathrm{a}$ & $10 \pm 0 \mathrm{a}$ & a \\
\hline SL & $\mathrm{N} / \mathrm{D}$ & $\begin{array}{l}25.6 \pm \\
0.5\end{array}$ & $\mathrm{R}$ & $\mathrm{R}$ & $\begin{array}{l}21.9 \pm \\
0.05\end{array}$ & $\begin{array}{l}14.1 \pm \\
0.28\end{array}$ & $\begin{array}{l}25.8 \pm \\
0.28\end{array}$ & $\begin{array}{l}13.1 \pm \\
0.17\end{array}$ & $20 \pm 0 \mathrm{a}$ & $\mathrm{a}$ & a & $20 \pm 0 \mathrm{a}$ & $\begin{array}{c}17.9 \pm \\
0.17 \mathrm{~s}\end{array}$ & $\begin{array}{l}14.9 \pm \\
0.17 \mathrm{a}\end{array}$ & $\mathrm{a}$ \\
\hline SA & $\mathrm{N} / \mathrm{D}$ & $26 \pm 0$ & $\mathrm{R}$ & $\mathrm{R}$ & $\begin{array}{l}22.1 \pm \\
0.1\end{array}$ & $\begin{array}{l}22 \pm \\
0.2\end{array}$ & $\begin{array}{l}26.1 \pm \\
0.17\end{array}$ & $\begin{array}{l}17.2 \pm \\
0.34\end{array}$ & $25 \pm 0 \mathrm{a}$ & $\mathrm{a}$ & $\mathrm{a}$ & A & $\begin{array}{l}18.9 \pm \\
0.17 \mathrm{a}\end{array}$ & $\begin{array}{l}14.86 \pm \\
0.23 \mathrm{a}\end{array}$ & $10 \pm 0 \mathrm{a}$ \\
\hline $\mathrm{CF}$ & $\mathrm{N} / \mathrm{D}$ & $22 \pm 0$ & $\mathrm{R}$ & $\mathrm{R}$ & $\begin{array}{l}22.3 \pm \\
0.5\end{array}$ & $16 \pm 0$ & $\begin{array}{l}23.7 \pm \\
0.57\end{array}$ & $12 \pm 0$ & $\begin{array}{l}30.06 \pm \\
0.11 \mathrm{~s}\end{array}$ & $\mathrm{a}$ & $\mathrm{a}$ & $\begin{array}{l}21.9 \pm \\
0.17 \mathrm{a}\end{array}$ & $23 \pm 0 \mathrm{~s}$ & $25 \pm 0 \mathrm{~s}$ & $\begin{array}{l}15.06 \pm \\
0.11 \mathrm{~s}\end{array}$ \\
\hline
\end{tabular}

${ }^{\mathrm{a}} \mathrm{A}=$ Inhibition zones that occurred with essential oil (essential oil of Nigella sativa: $10 \mu \mathrm{L}$ ); B = Inhibition zones that occurred with standard antibiotic disc, levofloxacin (L), oxacillin (O), amoxicillin (M), chloramphenicol (C), gentamicin $(\mathrm{CN})$, tetracycline $(\mathrm{T})$, and streptomycin $(\mathrm{P}) ; \mathrm{C}=$ Inhibition zones that occurred when essential oil and standard antibiotic were used together, (essential oil of Nigella sativa $10 \mu \mathrm{L} /$ disc); $(\mathrm{NS}=$ Nigella sativa; $\mathrm{EC}=$ Escherichia coli; $\mathrm{SF}=$ Serratia fonticola $; \mathrm{SL}=$ Serratia liquefaciens; $\mathrm{CF}=$ Citrobacter freundii; $\mathrm{SA}=$ Staphylococcus aureus; $/ \mathrm{D}=$ no antibacterial activity detected; $\mathrm{s}=$ Synergism effect; $\mathrm{e}=$ Additive effect; $\mathrm{a}=$ Antagonistic effect; $\mathrm{i}=$ Indifference; $\mathrm{R}=$ resistant; Values are represented as Mean $\pm \mathrm{SD}$ ). 
Table 8. Antibacterial activity of combined effects of essential oils Citrus limon and lavandula angustifolia (CCL) by agar well diffusion method ${ }^{\mathrm{a}}$

\begin{tabular}{|c|c|c|c|c|c|}
\hline \multirow[t]{3}{*}{ EO conc. } & \multicolumn{5}{|c|}{ Bacterial strains } \\
\hline & \multicolumn{5}{|c|}{ Zone of inhibition in millimeter $(\mathrm{mm})$} \\
\hline & Escherichia coli & $\begin{array}{l}\text { Citrobacter } \\
\text { freundii }\end{array}$ & $\begin{array}{l}\text { Serratia } \\
\text { liquefaciens }\end{array}$ & $\begin{array}{l}\text { Staphylococcus } \\
\text { aureus }\end{array}$ & $\begin{array}{l}\text { Serratia } \\
\text { fonticola }\end{array}$ \\
\hline $\mathrm{CCL} 1000 \mu \mathrm{g} / \mathrm{mL}$ & $15 \pm 0$ & $\mathrm{~N} / \mathrm{D}$ & $\mathrm{N} / \mathrm{D}$ & $15 \pm 0$ & $30.33 \pm 0.57$ \\
\hline $\mathrm{CCL} 500 \mu \mathrm{g} / \mathrm{mL}$ & $24.8 \pm 0.28$ & $\mathrm{~N} / \mathrm{D}$ & $15 \pm 0$ & $15 \pm 0$ & $35.06 \pm 0.11$ \\
\hline CCL (undiluted) & $15.1 \pm 0.23$ & $\mathrm{~N} / \mathrm{D}$ & $\mathrm{N} / \mathrm{D}$ & $15 \pm 0$ & $40.4 \pm 0.50$ \\
\hline
\end{tabular}

${ }^{\mathrm{a}} \mathrm{N} / \mathrm{D}=$ No antibacterial activity detected.

\section{Conclusion}

The fundamental reason of this study is to decrease drug resistance by combining classical antibiotics and essential oils. Association of essential oils and antibiotics and the combination of essential oils exhibited synergistic effect which is beneficial for making new antimicrobial agents that have great potential to fight against infectious diseases. This synergistic effect also enhances the antibacterial activity of the respective antibiotics which become ineffectual due to increase in the drug resistance. It can be used as antibacterial supplement in the developing countries in the direction of the development of new therapeutic agents. Acquired antagonistic results due to the interaction of antibiotics and essential oils can cause side effects. This investigation propose the advanced studies on molecular level in a manner that the interactions of antimicrobial agents increased the selective toxicity of drugs, therefore in vivo studies would be necessary to evaluate the antibacterial potential of these essential oils.

Conflict of Interest. The authors declare no conflict of interest.

\section{References}

Abascal, K., Yarnell, E. 2002. Potential of botanical in drug-resistant microbes. Herbs and drug resistance. Part-1. American Botanical Council. Herbalgram Org. Alternative and Complementary Therapies, 1: 237-241.

Angulo, F.J., Collignon, P., Powers, J.H., Chiller, T.M., Aidara-Kane, A., Aarestrup, F.M. 2009. World Health Organization ranking of antimicrobials according to their importance in human medicine: a critical step for developing risk management strategies for the use of antimicrobials in food production animals. Clinical Infectious Diseases, 49: 132-141.

Barry, A.L. 1990. Antistaphylococcal activity of amoxicillin and ticarcillin when combined with clavulanic acid evaluation of oxacillin-resistant and oxacillin-susceptible isolates. Diagnostic Microbiology and Infectious Disease, 13: 357-361.

Brooks, G., Butel, J., Ornston, L., Jawetz, E., Melnick, J., Adelberg, E. 1995. Medical Microbiology, pp. $410-442.20^{\text {th }}$ eds. Appleton \& Lange, East Norwalk.

Buckle, J. 2014. Clinical Aromatherapy-E-Book: Essential Oils in Practice, 342 pp., $3^{\text {rd }}$ edition, Elsevier Health Sciences, London, UK.

Canini, N.D., Bala, J.J.O., Maraginot, E.N., Mediana, B.C.B. 2013. Evaluation of street food vending in Ozamiz city. Journal of Multidisciplinary Studies, 1: 104-124.

Cavanagh, H., Wilkinson, J. 2002. Biological activities of lavender essential oil. Phytotherapy Research, 16: 301-308.

Cruz, M., Santos, P., Barbosa Jr, A., De mélo, D., Alviano, C., Antoniolli, A., Alviano, D., Trindade, R. 2007. Antifungal activity of Brazilian medicinal plants involved in popular treatment of mycoses. Journal of Ethnopharmacology, 111: 409-412.

De Rapper, S., Kamatou, G., Viljoen, A., Van Vuuren, S. 2013. The in vitro antimicrobial activity of Lavandula angustifolia angustifolia essential oil in combination with other aroma-therapeutic oils. Evidence-Based Complementary and Alternative Medicine, 2013.

Deans, S., Ritchie, G. 1987. Antibacterial properties of plant essential oils. International Journal of Food Microbiology, 5: 165-180.

Defrancesco, K.A., Cobbold, R.N., Rice, D.H., Besser, 
T.E., Hancock, D.D. 2004. Antimicrobial resistance of commensal Escherichia coli from dairy cattle associated with recent multi-resistant salmonellosis outbreaks. Veterinary Microbiology, 98: 55-61.

Delaquis, P.J., Stanich, K., Girard, B., Mazza, G. 2002. Antimicrobial activity of individual and mixed fractions of dill, cilantro, coriander and eucalyptus essential oils. International Journal of Food Microbiology, 74: 101-109.

Evans, W. 2002. Trease and Evans' Pharmacognosy, pp. $21-24,15^{\text {th }}$ edition, Chapter 6, Elsevier Health Sciences, New York, USA.

Faleiro, M.L. 2011. The mode of antibacterial action of essential oils. Science Against Microbial Pathogens: Communicating Current Research and Technological Advances, 2: 1143-1156.

Fisher, K., Phillips, C. 2009. In vitro inhibition of vancomycin-susceptible and vancomycin-resistant Enterococcus faecium and E. faecalis in the presence of citrus essential oils. British Journal of Biomedical Science, 66: 180-185.

Ginsberg, C., Zhang, Y.-H., Yuan, Y., Walker, S. 2006. In vitro reconstitution of two essential steps in wall teichoic acid biosynthesis. ACS Chemical Biology, 1: 25-28.

Guynot, M., Ramos, A., Seto, L., Purroy, P., Sanchis, V., Marin, S. 2003. Antifungal activity of volatile compounds generated by essential oils against fungi commonly causing deterioration of bakery products. Journal of Applied Microbiology, 94: 893-899.

Hammer, K.A., Carson, C.F., Riley, T.V. 1999. Antimicrobial activity of essential oils and other plant extracts. Journal of Applied Microbiology, 86: $985-990$.

Han, J., Weng, X., Bi, K. 2008. Antioxidants from a Chinese medicinal herb Lithospermum erythrorhizon. Food Chemistry, 106: 2-10.

Hili, P. 2001. The Antimicrobial Properties of Essential Oils. Winter Press, Kent, UK.

Holt, J., Krieg, N., Sneath, P., Staley, J., Williams, S. 1994. Bergey's manual of determinative microbiology. Williams and Wilkins, Maryland.

Janssen, A.M., Scheffer, J.C., Svendsen, A.B., Aynehchi, Y. 1985. Composition and antimicrobial activity of the essential oil of Ducrosia anethifolia. Essential Oils and Aromatic Plants, 213-216.

Kim, J., Marshall, M.R., Wei, C.-I. 1995. Antibacterial activity of some essential oil components against five foodborne pathogens. Journal of Agricultural and Food Chemistry, 43: 2839-2845.

Lawless, J. 1995. The Illustrated Encyclopedia of Essential Oils: The Complete Guide to the Use of Oils in Aromatherapy and Herbalism. Element Books, Ltd., Re issue Edition, Shaftesbury, Dorset, UK.

Liu, Z.-H., Nakano, H. 1996. Antibacterial activity of spice extracts against food-related bacteria. Journal of the Faculty of Applied Biological ScienceHiroshima University (Japan).

Lopes-Lutz, D., Alviano, D.S., Alviano, C.S., Kolodziejczyk, P.P. 2008. Screening of chemical composition, antimicrobial and antioxidant activities of Artemisia essential oils. Phytochemistry, 69: 1732-1738.

Mahmoud, A.M., EL-Baky, R.M.A., Ahmed, A.B.F., Gad, G.F.M. 2016. Antibacterial activity of essential oils and in combination with some standard antimicrobials against different pathogens isolated from some clinical specimens. American Journal of Microbiological Research, 4: 16-25.

Martins, S., Amorim, E.L., Sobrinho, T.J.P., Saraiva, A.M., Pisciottano, M.N., Aguilar, C.N., Teixeira, J.A., Mussatto, S.I. 2013. Antibacterial activity of crude methanolic extract and fractions obtained from Larrea tridentata leaves. Industrial Crops and Products, 41: 306-311.

Mehboob, A., Abbas, T. 2019. Evaluation of microbial quality of street food in Karachi City, Pakistan: An epidemiological study. Microbiology Research, 10: https:11doi.org/10.4081/mr.20197463,

Moussaoui, F., Alaoui, T. 2016. Evaluation of antibacterial activity and synergistic effect between antibiotic and the essential oils of some medicinal plants. Asian Pacific Journal of Tropical Biomedicine, 6: 32-37.

Pasha, A., Abbas, T., Ali, T.M., Hasnain, A. 2018. Inactivation of food borne pathogens by lipid fractions of culinary condiments and their nutraceutical properties. Microbiology Research, 9:

Paterson, D.L. 2006. Resistance in gram-negative bacteria: Enterobacteriaceae. American Journal of Infection Control, 34: S20-S28.

Pichersky, E., Noel, J.P., Dudareva, N. 2006. Biosynthesis of plant volatiles: nature's diversity and ingenuity. Science, 311: 808-811.

Prabuseenivasan, S., Jayakumar, M., Ignacimuthu, S. 
2006. In vitro antibacterial activity of some plant essential oils. BMC Complementary and Alternative Medicine, 6: 39 .

Randhawa, M.A., Al-Ghamdi, M.S. 2002. A review of the pharmaco-therapeutic effects of Nigella sativa. Pakistan Journal Medical Research, 41: 77-83.

Rios, J., Recio, M. 2005. Medicinal plants and antimicrobial activity. Journal of Ethnopharmacology, 100: $80-84$.

Shealy, C.N. 1998. The Illustrated Encyclopedia of Healing Remedies: Over 1, 000 Natural Remedies for the Prevention, Treatment and Cure of Common Ailments and Conditions, Element Book Ltd.

Silva, A., Silva, T., Franco, E., Rabelo, S., Lima, E., Mota, R., Da Câmara, C., Pontes-Filho, N., LimaFilho, J. 2010. Antibacterial activity, chemical composition, and cytotoxicity of leaf's essential oil from Brazilian pepper tree (Schinus terebinthifolius, Raddi). Brazilian Journal of Microbiology, 41: 158-163.

Singh, P.K., Tack, B.F., Mccray Jr, P.B., Welsh, M.J.
2000. Synergistic and additive killing by antimicrobial factors found in human airway surface liquid. American Journal of Physiology-Lung Cellular and Molecular Physiology, 279: L799L805.

Threlfall, E.J., Ward, L.R., Frost, J.A., Willshaw, G.A. 2000. The emergence and spread of antibiotic resistance in food-borne bacteria. International Journal of Food Microbiology, 62: 1-5.

Toroglu, S. 2007. In vitro antimicrobial activity and antagonistic effect of essential oils from plant species. Journal of Environmental Biology, 28: 551-559.

Weerakkody, N.S., Caffin, N., Turner, M.S., Dykes, G.A. 2010. In vitro antimicrobial activity of lessutilized spice and herb extracts against selected food-borne bacteria. Food Control, 21: 1408-1414.

Yücel, N., Cýtak, S., Önder, M. 2005. Prevalence and antibiotic resistance of Listeria species in meat products in Ankara, Turkey. Food Microbiology, 22: 241-245. 